\title{
Evolution of the EU Ecological Products Market
}

\author{
Laura Cătălina Țimiraş - Vasile Alecsandri University, Bacau, Romania \\ Luminiţa Zaiț - Vasile Alecsandri University, Bacau, Romania
}

\begin{abstract}
The ecologic products market has registered on the EU countries level a hightened dynamic. Yearly there is a growing number of european ecologic labels granted, labels that are only granted to some classes of non-food products, proving this way the orientation of more and more producers towards producing products with a low impact on environment according to the requirements of the consumers on the markets they perform on. In regard to the ecologic food products market there is a significant growth in the consumption of such products and in close connection to their cultivating areas in agreement with the regulations regarding the agricultural ecologic products. The dynamic of the ecologic products is justified by the evergrowing ackowledgment at public opinion level of the necessity to protect the environment, of the role of consuming ecologic products and therefore of giving up the consumption of polluting products that will ensure a longlasting development, by increasing the requirements of the consumers that orientate themselves towards products that can guarantee their present and future safety and security.
\end{abstract}

\section{Keywords}

market, ecologic product, European ecologic label, ecologic agriculture

\section{Introductive Elements}

The EU ecologic products market is ever extending. Result of the increasing requirements of the consumers who become more and more receptive to the assessment criteria of products such as ,ecologic”, „biologic”, ,unpolluted”, natural”, etc, of the ackowledgment of the public opinion regarding the importance of the environmental protection, ensuring the security and safety of the consumers, more and more producers address the market with products adapted to the new requirements. The competitive advantage of these „healthy” products for the consumer/user, respectively the enviroment in itself is highlightened on the wrap of the market by the ecologic marking, legislation of the European Union offering specific labeling schemata of the food ${ }^{1}$ and non-food ${ }^{2}$ products. Actully, the „ecologic" criterium is for the consumers an inssurance of the product's quality, thus increasing the notoriety of the producers who are concerned with the problem of a longlasting development.

\footnotetext{
1 Council Regulation (EC) No 834/2007 on organic production and labelling of organic products; Commission Regulation (EC) No 889/2008 of 5 September 2008 laying down detailed rules for the implementation of Council Regulation (EC) No 834/2007 (http://www.mmediu.ro)

${ }^{2}$ Regulation (EC) No 1980/2000 of the European Parliament and of the Council, on a revised Community eco-label award scheme; Regulation (EC) No 66/2010 Of The European Parliament And Of The Council Of 25 November 2009 On The EU Ecolabel (http://www.madr.ro)
} 
According to the community legislation for a wide range of non-food products, including cleaning products, paper products, electronic and house-electronic products, products for house and garden, showear, textile, etc and services for camping and tourism there is the European ecologic label applied. The products that contain on their wrappings the European ecologic label are products that on their entire life course - from raw material to eliminating/recycling phase or their re-use phase have a low impact on the environment, by protecting the air, water, soil and ozone quality contribute to saving energy, are made of recycling materials, etc.

In what the food products are concerned, the ecologic trait (biologic or organic) can be high- lightened by the EU organic farming logo. A food product that has the EU logo of "Organic Farming" on it is made of at least 95\% ingredients produced according to the ecologic production method. According to the Regulation (CE) no. $834 / 2007$ the organic production is a global system of agricultural management and food production that combines the best environmental techniques, a high level of biodiversity, preserving the natural resources, applying several high standards regarding the welfare of animals and a production technique that observes the preferences of certain consumers for products obtained with the help of some natural substances and processes.

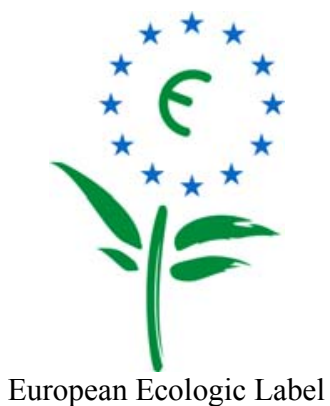

European Ecologic Label

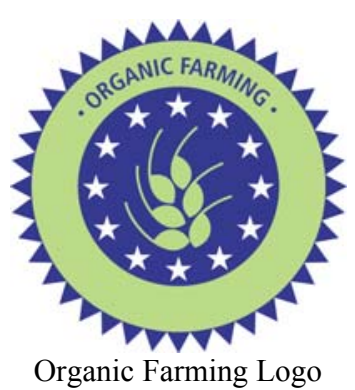

Organic Farming Logo

Figure no. 1. Marks showing the biologic trait of products used on the EU market

Source: http://ec.europa.eu/environment/ecolabel/index_en.htm; http://ec.europa.eu/agriculture/organic/home_ro

Besides the above-mentioned schemata, at EU level there are used much more ecologic applicable labels for various groups of products.

One image regarding the development of market of the non-food ecologic products, respectively those groups of products to whom according to the community regulations can applied the European ecologic label, is highlightened in the hereby article by means of the evolution of European ecologic label number registered at EU level.

In what the dimension and evolution of ecologic agro-food products market is concerned, they are sketched in terms of the public consumption, as well as in terms of the areas planted ecologically at EU countries level.

\section{The Development in the Number of European Ecologic Labels Registered at EU Level}

The development of the European ecologic products market is highlightened by the evergrowing number of the ecologic labels registered at EU level. Answering to the requirements of the consumers, of the society on the whole, in what the orientation 
towards products with a low impact on the environment is concerned, more and more producers have gained the right to use European ecologic labels. In 2010 (month of February) at the level of the 27 EU member-states there were 957 labels registered. The increasing requirements specific to the consumers in the EU countries with a high level of development stand out from this point of view, also, most of ecologic labels being registered in Italy, France, Germany, Spain, Denmark and Austria. Besides the exact number of ecologic labels registered at EU countries level, table no. 1 highlightens the increasing dynamic (at least in the case of the countries for which we have data on) that this pointer has known for the period $2001-2010$. For example, in Italy, the country that registers the highest number of ecologic labels $(35,6 \%$ per whole labels registered at EU level - 27 in 2010), the end of the analyzed period meant surpassing the year 2001 by 26 times; in France the growth was of 11 times and in Germany of 66 times.

In February 2010, Romania registered 4 ecologic labels, the market for these products being at a starting point (similar to the markets of some countries who just joined the EU).

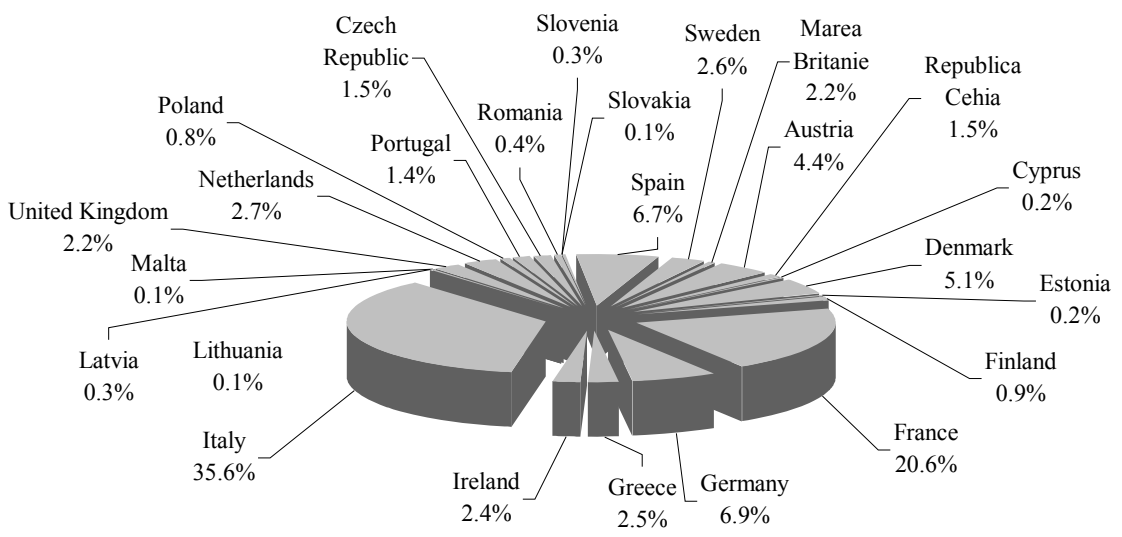

Figure no. 2. Distribution of the European ecologic trademarks on EU countries, in February (\%)

Source: adaptation after http://www.eco-label.com/romanian

Table no. 1. The number of Ecologic European Labels registered in EU countries between 2001-2010 


\begin{tabular}{|c|c|c|c|c|c|c|c|c|c|}
\hline Anul & 2001 & 2002 & 2003 & 2004 & 2005 & 2006 & 2007 & 2008 & $\begin{array}{c}\text { februarie } \\
2010^{*}\end{array}$ \\
\hline \begin{tabular}{|l} 
European Union (27 \\
countries)
\end{tabular} & n.d. & n.d. & n.d. & n.d. & n.d. & n.d. & n.d. & 705 & 957 \\
\hline Austria & 0 & 1 & 2 & 7 & 11 & 12 & 29 & 24 & 42 \\
\hline Belgium & 1 & 2 & 2 & 2 & 4 & 4 & 6 & 10 & 12 \\
\hline Bulgaria & n.d. & n.d. & n.d. & n.d. & n.d. & n.d. & n.d. & 0 & 0 \\
\hline Cyprus & n.d. & n.d. & n.d. & 0 & 0 & 1 & 1 & 1 & 2 \\
\hline Denmark & 18 & 23 & 28 & 45 & 53 & 55 & 29 & 52 & 49 \\
\hline \begin{tabular}{|l|} 
Estonia \\
\end{tabular} & n.d. & n.d. & n.d. & 0 & 0 & 0 & 0 & 2 & 2 \\
\hline Finland & 2 & 1 & 1 & 2 & 3 & 3 & 5 & 6 & 9 \\
\hline France & 17 & 26 & 30 & 43 & 45 & 50 & 89 & 137 & 197 \\
\hline Germany & 1 & 2 & 4 & 7 & 13 & 21 & 29 & 51 & 66 \\
\hline Greece & 9 & 9 & 10 & 14 & 6 & 16 & 19 & 21 & 24 \\
\hline Ireland & 1 & 1 & 0 & 0 & 0 & 9 & 11 & 20 & 23 \\
\hline Italy & 13 & 23 & 34 & 54 & 82 & 95 & 160 & 237 & 341 \\
\hline \begin{tabular}{|l|} 
Latvia \\
\end{tabular} & n.d. & n.d. & n.d. & 0 & 0 & 0 & 3 & 3 & 3 \\
\hline Lithuania & n.d. & n.d. & n.d. & 0 & 0 & 0 & 0 & 1 & 1 \\
\hline Luxembourg & 0 & 0 & 0 & 0 & 0 & 0 & 0 & 0 & 0 \\
\hline Malta & n.d. & n.d. & n.d. & n.d. & 0 & 1 & 1 & 1 & 1 \\
\hline United Kingdom & 1 & 2 & 2 & 4 & 5 & 7 & 12 & 17 & 21 \\
\hline Netherlands & 2 & 2 & 3 & 11 & 11 & 11 & 9 & 17 & 26 \\
\hline Poland & n.d. & n.d. & n.d. & 0 & 2 & 3 & 6 & 8 & 8 \\
\hline Portugal & 2 & 3 & 4 & 5 & 5 & 6 & 7 & 12 & 13 \\
\hline Czech Republic & n.d. & n.d. & n.d. & 0 & 1 & 2 & 8 & 13 & 14 \\
\hline Romania & n.d. & n.d. & n.d. & n.d. & n.d. & n.d. & n.d. & 3 & 4 \\
\hline \begin{tabular}{|l|} 
Slovakia \\
\end{tabular} & n.d. & n.d. & n.d. & 0 & 0 & 0 & 0 & 1 & 1 \\
\hline \begin{tabular}{|l|} 
Slovenia \\
\end{tabular} & n.d. & n.d. & n.d. & 0 & 0 & 4 & 2 & 3 & 3 \\
\hline Spain & 12 & 12 & 13 & 16 & 19 & 21 & 28 & 41 & 64 \\
\hline Sweden & 9 & 8 & 10 & 13 & 15 & 16 & 20 & 21 & 25 \\
\hline Hungary & n.d. & n.d. & n.d. & 0 & 1 & 1 & 2 & 3 & 6 \\
\hline
\end{tabular}

\section{The Consumership of Ecologic Agro-Food Products}

The dynamic of ecologic agro-food products registered in EU countries is accelerated. In spite of the fact that we refer to food products, for which the sales dynamic is often stationery, due to inelastic character of the demand, the "biologic" character imprints on the markets of these products distinctive traits. In fact, we are not talking of an increase in demand of food products, but of a reorientation of such to the healthy products, that will answer to some increased requirements linked to the food safety and security of the population.

The European market ${ }^{3}$ of the ecologic products has reached in 2007 (according to the data we have) the level of 16 billion Euro; 4 of the EU countries have registered over $73 \%$ from the total of this market, respectively: Germany- 5,3 billion Euro, Great Britain $-2,6$ billion Euro, as well as France and Italy - both with 1,9 billion Euro. ${ }^{4}$

Between the years $2000-2006$ one can notice (table nr. 2) increases in the sales of ecologic agro-food products in all EU countries, most of these markets having, approximately, doubled their dimensions.

The countries that stand out at EU level by their average shopping for ecologic agrofood products per person are: Denmark, Austria, Germany, Great Britain and Sweden. In Romania the ecologic agro-food products had in 2006 a dimension of only 3 million de Euro, thus placing itself from this point of view last in the EU countries for which we have data.

\footnotetext{
${ }^{3}$ concerns the entire European market, not only the EU market

4 Source: The World Of Organic Agriculture Statistics And Emerging Trends 2009 (http://orgprints.org).
} 
Table no. 2. The development of the average sales and expenses per person for ecologic agro-food products in some EU countries, between the years 2000 - 2006

\begin{tabular}{|c|c|c|c|c|c|}
\hline \multicolumn{6}{|c|}{ Sales of ecologic agro-food products } \\
\hline Year & $2000^{\text {a) }}$ & $2002^{b)}$ & $2003^{b)}$ & $2005^{c)}$ & $2006^{d)}$ \\
\hline Measurement unit & million \$ & billion Euro & \multicolumn{3}{|c|}{ million Euro } \\
\hline Austria & $250-275$ & 0.33 & 323 & 450 & 530 \\
\hline Belgium & n.d. & 0.30 & 300 & n.d. & 245 \\
\hline Denmark & $350-375$ & 0.27 & 339 & 307 & 434 \\
\hline Finland & n.d. & n.d. & 212 & 80 & 57 \\
\hline France & $800-850$ & 1.50 & 1578 & 2200 & 1700 \\
\hline Germany & $2200-2400$ & 3.00 & 3100 & 3900 & 4600 \\
\hline Greece & n.d. & 0.02 & 21 & 50 & n.d. \\
\hline Ireland & n.d. & n.d. & n.d. & 66 & n.d. \\
\hline Italy & $1000-1050$ & 1.38 & 1400 & 2400 & 1900 \\
\hline United Kingdom & $1000-1050$ & 1.44 & 1607 & 2333 & 2831 \\
\hline Netherlands & $225-250$ & 0.38 & 395 & 419 & 460 \\
\hline Poland & n.d. & n.d. & n.d. & 30 & 20 \\
\hline Portugal & n.d. & n.d. & n.d. & 50 & n.d. \\
\hline Czech Republic & n.d. & n.d. & 6 & 12 & 26.8 \\
\hline Romania & n.d. & n.d. & n.d. & n.d. & 3 \\
\hline Slovakia & n.d. & n.d. & n.d. & n.d. & 4.3 \\
\hline Spain & n.d. & n.d. & 144 & 300 & 70 \\
\hline Sweden & $175-200$ & 0.40 & 420 & 433 & 379 \\
\hline Hungary & n.d. & n.d. & 18 & 5.6 & 7 \\
\hline
\end{tabular}

Follow-up table no. 2

\begin{tabular}{|c|c|c|c|c|c|}
\hline \multicolumn{6}{|c|}{ Expenses for ecologic agro-food products/person } \\
\hline Year & $2000^{e)}$ & $2002^{b)}$ & $2003^{b)}$ & $2005^{c)}$ & $2006^{d)}$ \\
\hline Measurement unit & \multicolumn{5}{|c|}{ Euro / person } \\
\hline Austria & 40.0 & 41 & 40 & 56 & 64 \\
\hline Belgium & n.d. & 29 & 29 & n.d. & 23 \\
\hline Denmark & 72.0 & 50 & 51 & 57 & 80 \\
\hline Finland & n.d. & n.d. & 41 & 15 & 11 \\
\hline France & 14.0 & 25 & 27 & 37 & 27 \\
\hline Germany & 31.0 & 36 & 38 & 47 & 56 \\
\hline Greece & n.d. & n.d. & 2 & 5 & n.d. \\
\hline Ireland & n.d. & n.d. & n.d. & 16 & n.d. \\
\hline Italy & 17.0 & 24 & 24 & 42 & 32 \\
\hline United Kingdom & 16.0 & 24 & 27 & 39 & 47 \\
\hline Netherlands & 15.0 & 23 & 25 & 29 & 28 \\
\hline Poland & n.d. & n.d. & n.d. & 0.8 & 1 \\
\hline Portugal & n.d. & n.d. & n.d. & 5 & n.d. \\
\hline Czech Republic & n.d. & n.d. & 1 & 1.2 & 3 \\
\hline Romania & n.d. & n.d. & n.d. & n.d. & 0.1 \\
\hline Slovakia & n.d. & n.d. & n.d. & n.d. & 1 \\
\hline Spain & n.d. & n.d. & 4 & 7 & 2 \\
\hline Sweden & n.d. & 45 & 47 & 48 & 42 \\
\hline Hungary & n.d. & n.d. & 2 & 0.6 & 1 \\
\hline
\end{tabular}

Source:

a) estimated value, International Trade Centre

b) Research Institute of Organic Agriculture, Switzerland 
c) Agra Europe; Bio Plus / FiBL market survey: International expert survey; Rippin, M and Michels (2006) Beitrage zum ZMP Ökomarktworkshop, May 2006 Berlin; www.biofach.de; .Ökomarkt Forum of ZMP; Hamm, U. (2006) Viele Bioprodukte schwer zu bekommen. Meldung dpa; www.agencebio.org/; www.biomarkt.info; Richter, T (2006) Neue Herausforderungen jenseits der Nische. Ökologie \& Landbau, 01/2007; www.biologica.nl; www.ekoland.nl; Bio forum Vlaanderen; www.ekoconnect.org; Williamson, S, Cleeton, J and Nettleship, T (2006) Organic Market Report. Soil Association, Bristol; Lampkin, N, Measures, M and S. Padel (2006) 2007 Organic Farm Management Handbook. University of Wales, Aberystwyth.

d) Aberystwyth University/Institute of Rural Sciences; Agromilagro Research; Research Institute of Organic Agriculture, Switzerland; Central Market and Price Reporting Bureau in Germany

e) Research Institute of Organic Agriculture, Switzerland / Soil Association

According to:

Organic Agriculture Worldwide 2002, The World Of Organic Agriculture Statistics And Emerging Trends, 2003 - 2008 editions (http://www.soel.de/fachthemen/oekolandbau_welt.html)

Note: although the data presented are not compatible being a result from research done by a large number of organizations, often having an estimate character, it gives a whole image on the development registered by the ecologic products market at EU market level.

\section{The Development of the Areas Ecologically Cultivated at EU Level}

The areas that are cultivated in the EU countries according to the community regulations regarding the ecologic agricultural have been between the years 2000 2008 in an increasing spread - the growths exceeding sometimes 100\% (figure no. 3), proving by that an increase of the ecologic food and beverage offer at the level of reference markets.

The countries with the largest ecologic cultivated areas were: Italy -812139 ha., Spain - 691196 ha., Great Britain - 582205 ha., France - 502234 ha., according to the data associated with year 2008. Romania has registered in 2008 an ecologic cultivated area of only 71597 ha. $^{5}$

\footnotetext{
${ }^{5}$ Source: Eurostat 2010 (http://epp.eurostat.ec.europa.eu/portal).
} 


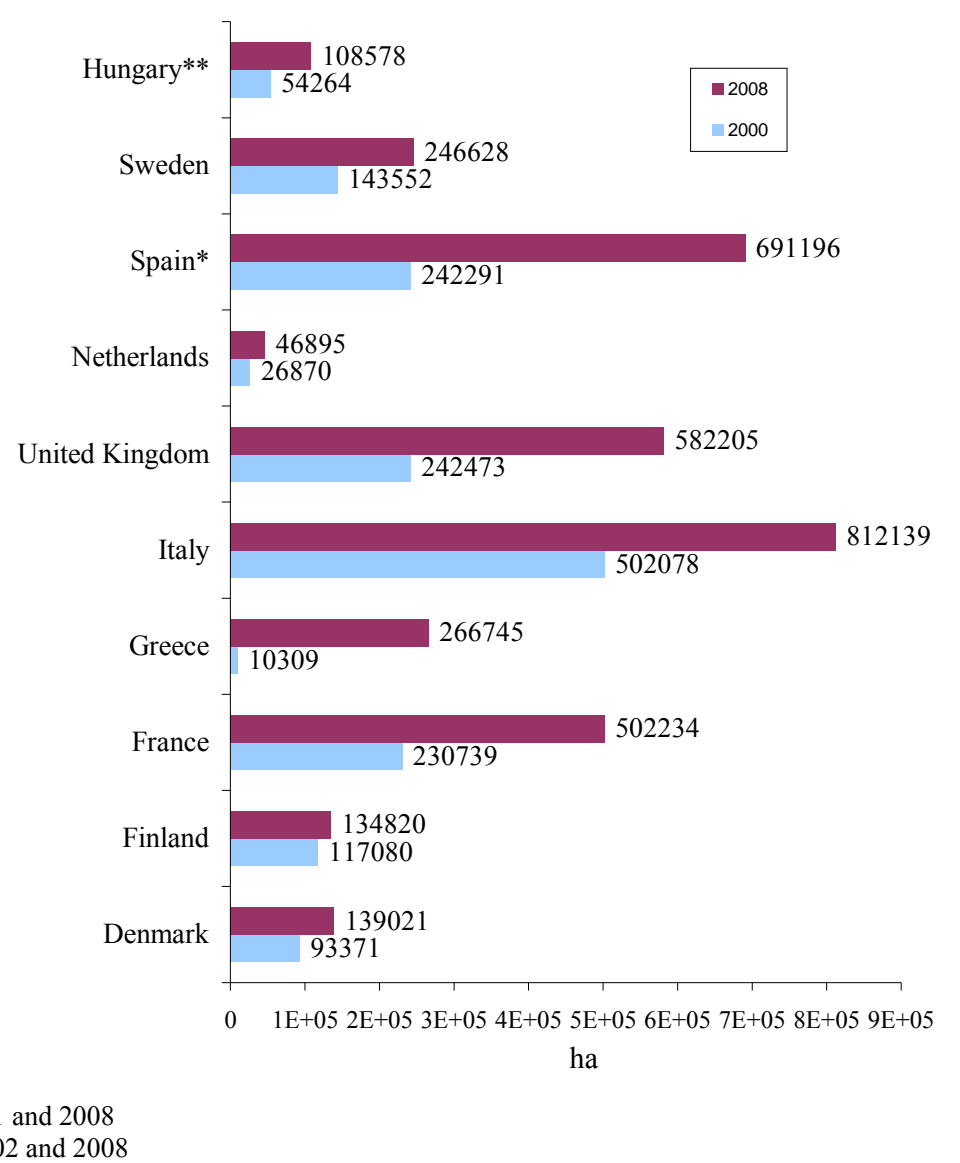

Figure no. 3. The Area of the organic cultures in some EU countries, in 2000 and 2008

Source: Eurostat 2010 (http://epp.eurostat.ec.europa.eu/portal)

A pointer much more relevant regarding the development of the ecologically cultivated areas is the weight factor it has in the total of the agricultural areas used. It is noticeable in almost all EU countries an increase from this point of view, proving thus the tendency of the producers to reorientate towards the ecologic production system and implicitly of adapting to the ever-growing demand for biologic food products. (table no. 3 ).

The biggest areas cultivated with ecologic agriculture per whole used agricultural area have been registered (according to the data associated with the year 2008) in Austria, Sweden, Latvia, Estonia, Czech Republic. There is notice that a part from the new EU members have orientated somewhat towards this type of production, surpassing this way even some old EU member-countries.

In the case of Romania the weight factor of the ecologically cultivated lands is extremely low (under 1\%) in spite of the potential it has from this point of view. 
Table no. 3. The Weight Factor of the Are Cultivated Ecologically per whole the Agicultural Area used in the EU Countries in the Period 2000 - 2007 (\%)

\begin{tabular}{|c|c|c|c|c|}
\hline Year & 2000 & 2003 & 2005 & 2007 \\
\hline European Union (15 countries) & $3.0^{*}$ & 4.0 & $4.3^{*}$ & $4.7^{*}$ \\
\hline Austria & 8.1 & 10.0 & 11.0 & 11.7 \\
\hline Belgium & 1.5 & 1.7 & 1.7 & 2.4 \\
\hline Bulgaria & n.d. & n.d. & n.d. & 0.4 \\
\hline Cyprus & n.d. & n.d. & 1.1 & 1.6 \\
\hline Denmark & 6.0 & 6.2 & 5.2 & $5.2^{*}$ \\
\hline Estonia & n.d. & n.d. & 7.2 & 8.8 \\
\hline Finland & 6.6 & 7.1 & 6.5 & 6.5 \\
\hline France & $1.3 *$ & 2.0 & 2.0 & 2.0 \\
\hline Germany & 3.2 & 4.3 & 4.7 & 5.1 \\
\hline Greece & 0.7 & 6.2 & 7.2 & 6.9 \\
\hline Ireland & 0.6 & 0.7 & 0.8 & 1.0 \\
\hline Italy & 8.0 & 8.0 & 8.4 & 9.0 \\
\hline Latvia & n.d. & n.d. & 7.0 & 9.8 \\
\hline Lithuania & n.d. & n.d. & 2.3 & 4.5 \\
\hline Luxembourg & 0.8 & 2.3 & $2.4^{*}$ & $2.4^{*}$ \\
\hline Malta & n.d. & n.d. & 0.1 & $0.2^{*}$ \\
\hline United Kingdom & 3.7 & 4.3 & 3.8 & 4.1 \\
\hline Netherlands & 1.6 & 2.1 & 2.5 & 2.5 \\
\hline Poland & n.d. & 0.2 & $0.6^{*}$ & $0.5^{*}$ \\
\hline Portugal & 1.2 & 3.2 & 6.3 & 6.7 \\
\hline Czech Republic & n.d. & 7.0 & 7.2 & 8.3 \\
\hline Romania & n.d. & n.d. & n.d. & $0.8^{*}$ \\
\hline \begin{tabular}{|l} 
Slovakia \\
\end{tabular} & n.d. & 2.3 & 4.8 & 6.1 \\
\hline \begin{tabular}{|l|} 
Slovenia \\
\end{tabular} & n.d. & 1.d. & 4.8 & 6.0 \\
\hline Spain & 1.5 & 2.9 & 3.2 & 4.0 \\
\hline Sweden & 5.7 & 7.2 & 7.0 & 9.9 \\
\hline Hungary & n.d. & 2.7 & 3.0 & 2.5 \\
\hline
\end{tabular}

As a conclusion, the ecologic products market - agro-food and non-food products in EU is an evergrowing market, fact proven by both the orientation of more and more producers towards producing products with low impact on environment, which guarantees the present and future safety and security of the consumers and the increased consumption of these products. In fact, the foundation of the development of these market lies firstly in the changes that appeared at the requirements level of the consumers in EU area, more and more aware of the necessity to protect the environment, but also more and more preoccupied with their health, which led to giving up polluting products, potentially harmfull to health in favour to the ecologic products.

\section{Bibliography}

1. Council Regulation (EC) No $834 / 2007$ on organic production and labelling of organic products

2. Regulation (EC) No 1980/2000 of the European Parliament and of the Council, on a revised Community eco-label award scheme

3. Organic Agriculture Worldwide 2002

4. The World Of Organic Agriculture Statistics And Emerging Trends, 2003 - 2009 editions

5. http://ec.europa.eu/agriculture/organic/home_ro 
6. http://www.eco-label.com/romanian

7. http://ec.europa.eu/environment/ecolabel/index_en.htm

8. http://epp.eurostat.ec.europa.eu/portal

9. http://www.mmediu.ro/departament_mediu/controlul_poluarii/eticheta_ecologica

10. http://www.madr.ro

11. http://orgprints.org 